\title{
TOURISM
}

\section{Features and prospects of event tourism in Ukraine on the example of Transcarpathian region}

\author{
V. F. Kaluha, S. I. Uliganets, L. V. Melnyk \\ National University of Life and Environmental Sciences of Ukraine, Kyiv National Taras Shevchenko University \\ Corresponding author. E-mail: kalugavl@ukr.net, uliganez@ukr.net, lysil@ukr.net
}

Paper received 10.09.18; Accepted for publication 15.09.18.

https://doi.org/10.31174/SEND-HS2018-178VI29-23

\begin{abstract}
The article analyzes event tourism development peculiarities in Transcarpathian region, as well as the types of events and their organization peculiarities. The general state, problems and prospects of development are highlighted, directions of event tourism government regulation in the context of border cooperation on the example of Transcarpathian region are defined in the article.
\end{abstract}

Keywords: professional assistance (accompaniment), attraction, event tourism, entertainments, event technology, destination.

The problem statement. In the world there is a certain process of refocusing the overwhelming majority of citizens of wealthy countries from business-related values to the values associated with pleasure from various educational and moderately extreme entertainments. Thus, event tourism and entertainments, special events respectively gain tangible importance and significance on the one hand as a desirable and as an integral element of the life of a civilized world secured representative. On the other hand, it is a business activity. In addition, the trend has a tendency to lively development and a broad, inexhaustible spectrum of practical fulfillment, as far as human imagination and ingenuity is able to reach.

On the one hand, the success of event tourism development depends on the concomitant and organizing circumstances, in particular the features of the legal field peculiarities and the socio-economic situation of the host party, and on the other - on the of event organizers' professionalism, their ability to plan sequence of events, to organize logistics, etc. Therefore, there is a need to research both the existing conditions and circumstances of event tourism development and the specifics of requests and expectations of potential service users from event tourism.

It should be kept in mind that tourism in general, and especially event tourism, is essentially linked to the socalled subjective factor. In other words, the organizer has to have professional skills, to identify and take into account the expectations of the client, respond promptly to his psychological state and emotional settings in order to create the optimal conditions to obtain the desired satisfaction.

In general, under efficient organization event tourism is one of the most profitable and dynamically developing sectors of the economy. Therefore, the study of the features and trends of the tourism industry as a fairly young branch of recreation and entertainment, has an obvious practical and theoretical meaning since it will certainly promote the development of new promising tourist and recreational services in different regions of Ukraine, in Transcarpathian region in particular.

Recent research and publications analysis. Numerous studies of both foreign and domestic specialists of various fields, including economists, internationalists, geographers, practitioners are devoted to the systematic study of the socio-cultural and, at the same time, socioeconomic phenomenon of tourism in its context to the event tourism as well. In particular, a group of German scholars consisting of E. Yettinger, B. Knause, R. Moser, W. Halzbaur, M. Zeller comprehends the essence and features of the organization and functioning of event services and event tourism in general from the networking with the public point of view, that is in the context of PRmanagement.

In his turn, R.F. Jany, one of the Walt Disney Entertainment Park's leaders, reveals the essence of events from the standpoint of direct practice: how meet the client expectations and/or give the most value to the events in his life, in particular, in the context of recreational - educational approach. O. Shumovich, member of AmCham and the international association of ISES, understands the essence and features of the organization of event tourism, taking into account the work of the scholars in the context of behaviorism. In the end, the subject study of event tourism and all that is associated with it are devoted to the scientific research of I. Antonenko, G. Vishnevskaya, Z. Gerasimchuk, V. Polischuk, A. Romantseva, I. Smal and many other thinkers and scholars. The scientists devote considerable attention to the event tourism development of the concept-categorical apparatus, the typology and classification of the events, the analysis of the place and role of tourism activity in the life of man and community, and the research methods improvement in the tourism sector.

At the same time, there is a tangible request for an indepth study of the event tourism as an innovative direction of tourism activity in the scientific and especially in business spheres. It should be done in view of the need of an effective concept for the management development of a promising tourism direction and, as a consequence, the provision of balanced sustainable regions development as tourist destinations.

Using a number of general scientific and special research methods has contributed to the achievement of its research objectives. In particular, it is about content analysis, which application allowed to study the available statistics systematically and interpret the results adequately. The review-critical method has helped authors to form a coherent vision of the situation regarding the state of event tourism development at the level of a specific desti- 
nation, Transcarpathian region namely.

The implementation of this task was also facilitated by using special methods, in particular the method of identifying competitive advantages and the comparing the level of competitiveness of the tourism sector. Of course, to obtain the result of verified knowledge and conclusions, the authors relied on general scientific methods in their research. They are, for example, inductive in combination with deductive, dialectical and historical-geographical methods.

To establish a representative opinion of travel services consumers, the authors had an express survey applying a number of statistical methods of research.

Presenting main material. In Ukrainian scientific and practical spheres, along with the concept of event tourism, the terminological construct -"entertainment tourism" - is used as its synonymic complement. However, according to the authors, the use of the very concept of event tourism is more effective in identifying a particular direction in the tourism sector related to the provision of a number of services, first of all, entertaining and at the same time recreational, educational, as well as an option, psychotherapeutic. Since the concept of "event" has fixed an informative content, which in a certain way overlooks all possible range of functions, the realization of which is able to provide event tourism. The language can be, for example, about the same psychotherapeutic function, which is realized as a result of purposeful filling of a tourist trip by special measures, for example, elements of moderately extreme sports, creation of extreme situations, etc.

At the same time, the concept of event tourism is used to define a purposefully organized system of entertainments (events) or event + placement. On the other hand, a marketing strategy aimed at achieving all potential economic benefits from an organized events (activities) or around events. At the same time, the authors are inclined to the idea that it is worthwhile to distinguish between a purposefully organized event or an activity and an event that may turn out to be potentially attractive to tourism, but it is caused by other motives or just naturally.

Thus, event tourism in general can be interpreted as a kind of tourism focused on visiting a certain locality at a certain time in case of particular organization, is connected primarily with an event, in our case - with a special event. Thus, the main resource of event tourism is a special event, for example, astronomical (sunset or something else), natural (animals migration) or other natural one, unlike the purposeful one.

In the framework of this study, the authors make an attempt to analyze the current state of tourism development in Transcarpathian region as a tourist destination. The analysis is based on the statistics and the results of the express survey conducted among students of different specialties of two leading universities of Ukraine: Kyiv Taras Shevchenko National University and National University of Life and Environmental Sciences of Ukraine. A group of 400 people was selected by random sampling, following a 50/50 proportion by gender. Both universities had roughly the same number of students, but there was a clear difference in educational and professional preferences.

According to various statistics the recreational poten- tial of Transcarpathian region it is quite high both in absolute terms and relatively to other regions of Ukraine. The combination of natural, climatic and socio-cultural factors, as well as preserved architectural ensembles and artistic heritage make the region a potentially interesting tourist center. Moreover, there are a lot of powerful recreational opportunities, resort areas on the Transcarpathia territory. Provided the organization of the operation is efficient, the event tourism is something new in the marketing plan and, to a certain extent, extraordinary. It has enormous potential to restore the interest in the given destination of those who have already had that experience of tourist trips toTranscarpathia, and to form the intention to visit the area of those who have not been interested in traditional forms of tourism to a sufficient extent so far. At the same time, event tourism as a new direction of economic activity can certainly contribute to the expansion and diversification of the consumer segment of various services, primarily related to tourist services. In particular, event tourism is likely to significantly expand the age and socio-economic ranges of those who would like to visit Transcarpathia as a tourist. The emphasis obviously should be on the fact that an effectively organized tourism event in Transcarpathia can attract both local and foreign tourists with practically unlimited financial opportunities. The latter, naturally, will promote among other things the additional attraction of tangible funds for the development of both socio-economic and socio-cultural spheres of the region.

Meanwhile, the analysis of reports and statistics along with the study of analytical reports and notes on the state of tourism development in Transcarpathia, placed on the pages of numerous regional periodicals and Internet portals, as well as reference literature allow to make conclusions that the tourism development in Transcarpathian region is not paid proper attention by any level of governance (from regional to state one). Significant touristoriented potential of the area is not used properly and to the fullest extent. In particular, the vast majority of events organized on the territory of the region are presented as a strictly defined events of artistic, sporting, business or other forms. In this way the recreational and entertainment component of events is cut off and therefore the potential for the development of the event tourism is ignored.

So, a certain idea of the correlation between the existing tourist and recreational potential and the level and status of the tourist destination development in Transcarpathian region can be formed through SWOT analysis. Among the other conclusions that can be drawn from comparative data in the table above, one should pay attention to the fact that event tourism can turn out to be an effective means of balancing the benefits and risks of tourism in Transcarpathia. Well-advertised events will allow you to get a constant inflow of tourists without overloading recreational areas and resources, thereby ensuring their conservation and recovery.

As for the attractiveness of Transcarpathia as a tourist zone from the event-tourism point of view, one can form a certain idea thanks to the results of the express survey mentioned above (see Table 1). Students, as representatives of the younger generation and its mobile and focused part, in a way reflect not only the current state of 
affairs in the community but also certain perspectives and tendencies inherent in society.

Approximately a quarter of students from both universities consider themselves to be tourists for the sake of attending or participating in various events-festivals, etc. At the same time, more than forty percent, again, students of both higher schools prefer regional exploring tourism. Among other things, this means that those who are ready to visit a region systematically or repeatedly are about twice less than those who make a one-time visit. It also means that events are either not sufficiently publicized or reporting of information about them is in need of better quality, or events themselves are not of great interest for various reasons (their irrelevance, improper organization or conduct).
But as for the choice of style and direction of events, the opinions of the students of two higher educational institutions are significantly different. Students of the classical university prefer sports and entertainment $26 \%$, ethnographic and educational $-17 \%$ and cultural and artistic $-16 \%$. While students at the university about life prefer gastronomy and eno-tourism $-21 \%$, otherwise they prefer to have a combination of just several events of a different nature $-64 \%$. There may be several reasons for such a clear disagreement. But at the moment it is important that event tourism should focus on a narrow interest and a combination of measures that would immediately satisfy several needs - cultural and artistic, ethnographic, gastronomic, etc in particular.

Table 1. Rapid survey results conducted among students of two national universities - KTShNU and NUBiP

\begin{tabular}{|c|c|c|}
\hline \multirow[t]{2}{*}{ Options } & \multicolumn{2}{|c|}{$\begin{array}{l}\text { Election of students as a percentage of } \\
\text { the total number of respondents }\end{array}$} \\
\hline & $\begin{array}{l}\text { KTShNU } \\
\text { people }\end{array}$ & $\begin{array}{l}\text { NULESU } \\
400 \text { people }\end{array}$ \\
\hline \multicolumn{3}{|l|}{ 1. What attracts you the most in tourism? } \\
\hline $\begin{array}{l}\text { 1.1. Traveling to unfamiliar places, enjoying the scenery and architecture, gaining } \\
\text { new experiences }\end{array}$ & 41 & 42 \\
\hline \begin{tabular}{|ll}
1.2. & The tendency to travel since childhood \\
\end{tabular} & 8 & 2 \\
\hline Opportunity to be a participant in entertainment events, including festivals & 24 & 28 \\
\hline $\begin{array}{l}\text { 1.4. Opportunity to distract from the usual environment and everyday events (train- } \\
\text { ing, work, etc.) }\end{array}$ & 12 & 23 \\
\hline Opportunity to get away in the company of the desired person & 15 & 5 \\
\hline \multicolumn{3}{|l|}{$2 . \quad$ How do you choose the travel route? } \\
\hline I listen to the friends and acquaintances recommendations & 4 & 8 \\
\hline I rely on a tour operator or organizer & 37 & 12 \\
\hline I decide what cities (countries) or natural complexes I would like to visit. & 26 & 34 \\
\hline I find out what events and activities I am interested in visiting & 32 & 46 \\
\hline It is random, maybe something interesting happens & 1 & - \\
\hline \multicolumn{3}{|c|}{$\begin{array}{l}\text { Are you ready to allocate time and money for a tourist trip for visiting various events (festivals, ceremonial cele- } \\
\text { brations, etc.)? }\end{array}$} \\
\hline No, I'm not interested in mass events & 54 & 23 \\
\hline Yes, I am attracted by festivals, other events & 24 & 31 \\
\hline Hard to say, it depends on circumstances. & 22 & 46 \\
\hline \multicolumn{3}{|l|}{$\begin{array}{ll}4 . & \text { What events do you prefer? }\end{array}$} \\
\hline Cultural and artistic & 16 & 4 \\
\hline Sports and entertainment & 26 & 8 \\
\hline Gastronomic and eno-tourism & 10 & 21 \\
\hline Ethnographic and educational & 17 & 3 \\
\hline Combining events of different character in one & 31 & 64 \\
\hline \multicolumn{3}{|l|}{$5 . \quad$ Have you ever been to Transcarpathia? } \\
\hline Yes, I'm originally from Transcarpathia or the neighboring territories & 5 & 2 \\
\hline Yes, I've travelled to Transcarpathia & 32 & 16 \\
\hline $\begin{array}{ll}5.3 . \quad \text { Yes, I was in a particular locality for personal (health nature, visiting friends) or } \\
\text { business reasons }\end{array}$ & 2 & 2 \\
\hline Yes, I was in a particular locality of tourist interest & 7 & 4 \\
\hline No, I have never been to & 52 & 76 \\
\hline $\begin{array}{r}\text { What attracted you to Transcarpathia as a tourist? (percentage of those who } \\
\text { to the absolute number of respondents) }\end{array}$ & o made a tourist trip to & o Transcarpathia and \\
\hline Interesting landscapes, good climate conditions & $2 / 0,8$ & $5 / 1$ \\
\hline Interesting architecture (castles, buildings, city planning) & $4 / 1,6$ & $10 / 2$ \\
\hline Possibility of walking, cycling tour, rafting on rivers, etc. & $12 / 4,7$ & $23 / 4,6$ \\
\hline Interesting events and festivals & $8 / 3,1$ & $15 / 3$ \\
\hline Possibility to combine types of holiday & $74 / 28,9$ & $47 / 9,4$ \\
\hline
\end{tabular}

As for Transcarpathia as a tourist destination, about a third of students are interested in it: $39 \%$ of students of KTShNU and $20 \%$ of students of NULESU. This is obviously a relatively low figure, considering that students are not the most mobile part of the youth. Naturally, accord- ing to such results, the general situation in the state is also visible - a significant part of the population can spend very limited resources on tourism.

As for the attractiveness of Transcarpathia as a vector of tourist aspirations, the figures in absolute percent indi- 
cate that it is interesting because it combines several options for satisfying tourist expectations at once. But as for the first-rate interest in various events (in particular festivals held in Transcarpathia) there is a very wide area to work on.

Meanwhile, the most famous events in Transcarpathia region are gastronomic and ethno-gastronomic festivals. They are held almost all the year-round. The program of these events is gradually filled with various entertaining elements in order to achieve maximum tourist satisfaction over time taking into account their individual requests and expectations.

Of course, one of the main goals of holding events of this format is the popularization of local culture, atmosphere and traditions. Various festivals, considering event tourism, serve as a popularization of the region to create an additional positive image of the destination. In addition, most festivals are characterized by systematic and regular happennings, which creates additional grounds for attracting a constant both local and foreign tourists inflow.

Gastronomic and ethno-gastronomic festivals in their essence have unlimited resource potential as they usually combine several national cuisines at once. The latter allows you to satisfy the gastronomic expectations of the most demanding tourists, regardless their age and social status. Such festivals are often of international importance, which allows to attract foreign tourists and foreign organizers. As a result, there is an experience exchange regarding event tourism and recreational potential development in particular.

Conclusions. Today event tourism is one of the most promising alternative types of tourism which is characterized by practically inexhaustible resource potential. Especially considering that the vast majority of the territory of Ukraine is not marked by historical, artistic and, moreover, architectural attractiveness. This is especially true about the central and eastern regions of Ukraine. Therefore, under the conditions of proper and effective special events organization, it is possible to ensure the development of tourism events, tourism in general and recreation even in those depressed regions with limited recreational potential. In this case, however, we must also consider the fact of the local population culture in terms of attitude towards tourists. We must take into account the readiness of residents of touristly unattractive regions to reconsider their behavior patterns in order to create a friendly atmosphere in the city or village. The absence of such an atmosphere seriously spoils the tourists' impressions about the place of their stay.

As for event tourism development in Transcarpathia region, considerable potential is evident due to the availability of favorable conditions and circumstances such as the mild climate, beautiful natural landscapes, unique historical and cultural heritage, originality, atmosphere and authenticity, etc. At the same time, the border area of the region contributes to the establishment of interaction and exchange of tourists between neighboring states. In addition, cooperation with European countries allows to organize special events of international importance that will promote new jobs, infrastructure development, transport routes and prosperity of the region as a whole, while creating a positive image for tourist destination.

At the same time, the active development of event tourism in Transcarpathia region is limited due to the lack of attention to the exceptional measures taken by the local, district, regional and state levels of government. This leads to significant problems related to regular financing, development of schemes and programs for event tourism as a promising industry and generates a range of threats.

Today one of the most widespread events systematically practiced in Transcarpathia region, are the festivals. Considerable popularity and interest among tourists are caused by special events related to gastronomy. Every year holiday-makers are attracted by the opportunity to visit a new or an annual event that allows them to enjoy traditional cuisine and experience the atmosphere of Hutsul and other ethnic cultures and a number of positive emotions.
1. Герасимчук 3.В. Регіональна політика івентивного туризму: методологічні засади формування та реалізації : монографія / Герасимчук 3.В., Поліщук В.Л. ; Луц. нац. техн. ун-т. - Луцьк : Волиньполіграф : Гадяк Ж.В., 2013. $256 \mathrm{c}$.

2. Калуга В.Ф.Знання як результат активності людини, особливості його набуття і верифікації / В.Ф. Калуга // Гуманітарні студії. Збірник наукових праць. Випуск 23 /

\section{ЛИТЕРАТУРА}

редкол.: А.Є. Конверський [та ін.]. - К. : Видавничополіграфічний центр «Київський університет», - 2014 - с. 27-37.

3. Getz D., Page, S.J. Event studies: Theory, research and policy for planned events. London, UK: Routledge. - 2016, - 217 p.

4. Goldblatt J. Special events: Creating and sustaining a new world for celebration (7th Edition). New York, NY: John Wiley \& Sons. - 2014. - 342 p.

\section{REFERENCES}

1. Gerasymchuk Z.V. Regional policy of occasional tourism: methodological principles of formation and implementation: monograph / Gerasymchuk Z.V., Polishchuk V.L. ; Luts. nats.tehn. u-tet. - Lutsk : Vilnopoligraf : Gadyak Zh.V., 2013. $-256 \mathrm{p}$.

2. Kaluha V.F. Knowledge as a result of human activity, especially its acquisition and verification // Gumanitarni studii. Zbirnyk naukovyh prats. Vypusk 23 / redkol. : A.Ye. Konverskyi [ta in.]. - K. :. Vydavnycho-poligrafichnyi tsentr "Kyivskyi universytet", $-2014-$ p. 27-37. 